\title{
Availability of dissolved organic carbon to bacterioplankton examined by oxygen utilization
}

\author{
Richard B. Coffin ${ }^{1}$, John P. Connolly ${ }^{2}$, Peggy S. Harris ${ }^{3}$ \\ ${ }^{1}$ U.S. EPA, GBERL, One Sabine Island Drive, Gulf Breeze, Florida 32561, USA \\ ${ }^{2}$ Environmental Engineering and Science Program, Manhattan College, Riverdale, New York 10471, USA \\ ${ }^{3}$ Technical Resources, Inc., One Sabine Island Drive, Gulf Breeze, Florida 32561, USA
}

\begin{abstract}
Oxygen consumption is used to study the dynamics of dissolved organic carbon (DOC) utilization by bacteria. Preliminary incubation experiments examining oxygen consumption and bacterial growth demonstrated that a small labile fraction of the total DOC pool typically supports bacterial metabolism. Bacterial growth and respiration rates were frequently fastest within the first few hours of incubation experiments suggesting that the pool of organic matter used for growth was rapidly consumed. Comparisons of bacterial production and respiration with total DOC concentrations suggested that approximately 1 to $3 \%$ of the pool supports bacterial growth. The presence of a small labile component of the DOC pool suggests a close coupling between bacteria and sources of substrate. Bacterial coupling to phytoplankton was examined in mesocosm experiments in which phytoplankton were enriched with nutrients and bacterial production and oxygen consumption were followed over diel cycles. Bacterial production, oxygen consumption and the availability of organic matter were highest during daylight, when phytoplankton production was assumed to be greatest. The effect of a varying carbon supply over diel cycles on bacterial growth efficiency was examined. During the mesocosm experiment, growth efficiencies were greatest during daylight when substrate availability was greatest. At several estuarine sites, efficiencies varied markedly over daily and seasonal temporal scâles. These results suggest that growth efficiency is an important consideration when estimating the bacterial role in aquatic carbon cycles
\end{abstract}

\section{INTRODUCTION}

Important to understanding the bacterial role in aquatic carbon cycles are a determination of the fraction of the total dissolved organic matter (DOM) pool metabolized and how efficiently bacteria grow on this material. With this information microbial ecologists can estimate the bacterial-mediated turnover of DOM and the amount of particulate carbon that bacteria provide to subsequent trophic levels. However, these processes are difficult to quantify because numerous allochthonous and autochthonous sources of DOM supply a large array of organic molecules with varying nutritional value to bacteria. Depending on the composition of the DOM pool and the ratio at which the various sources contribute to it, the activity and growth efficiency of bacteria will vary widely. Measurements of bacterial production in laboratory cultures indicate that the chemical speciation of substrate has a large effect on bacterial growth efficiency (Connolly et al 1992 and references therein). Values as high as 70\% are obtained for bacteria grown on amino acids. Intermediate growth efficiencies are measured for cells growing on alcohols and alkanes and for esters and organic acids, the efficiency is typically around $40 \%$. Even lower efficiencies, $20 \%$ or less, have been measured for bacteria grown on bulk dissolved organic carbon (DOC) in aquatic ecosystems (Meyer et al. 1987 Hopkinson et al. 1989, Griffith 1990, Connolly et al. 1992). The bacterial growth efficiency is also dependent on the elemental stoichiometry of the substrate (Goldman et al. 1987, Hopkinson et al. 1989, Kroer in press). The carbon-nitrogen ratio $(\mathrm{C}: \mathrm{N})$ of marine bacterial assemblages growing on substrates with $C: N$ varying between $1.5: 1$ and 10:1 was relatively constant at 5:1 (Goldman et al. 1987), thus requiring a reduction in carbon growth efficiencies at high substrate $C: N$. A more subtle factor that may affect 
bacterial growth efficiencies is the dynamic role of substrate supply and grazing pressure in controlling bacterial biomass and production. A logistics growth model has been used to suggest that bacteria growing in the absence of predation reach the system carrying capacity that is dictated by substrate; in this state the bacterial production rate and growth efficiency are low (Wright \& Coffin 1984a, b). Conversely, bacterial assemblages that are heavily grazed are predicted to have higher production rates and growth efficiencies. These predictions have only been supported in the field with indirect observations (Wright \& Coffin 1984a, Coffin \& Sharp 1987, Wright et al. 1987).

Difficulties with methods for measuring the bacterial utilization of organic matter may limit the ability of researchers to estimate the total bacterial carbon demand and growth efficiency. One approach has been to relate changes in the total DOC concentration to changes in bacterial biomass in incubation experiments lasting several days. However, bacterial production may be supported by a small fraction of the total DOM pool and measuring changes in the DOC concentration may approach the analytical limits of the technique. Radiotracer experiments, used to examine the turnover of specific pools of DOC, have demonstrated that small labile fractions of the bulk DOM may be turned over remarkably fast (Coffin 1989, Fuhrman 1990, Suttle et al. 1991). Even though the dissolved free amino acids are a small fraction of DOM, as a result of the rapid turnover times this pool may supply 20 to $64 \%$ of bacterial carbon and nitrogen requirements (Fuhrman 1990, Suttle et al. 1991). These radiotracer experiments suggest that long term experiments used to estimate growth efficiencies on the basis of changes in DOC concentration may overestimate the contribution of more refractory compounds to bacterial growth and underestimate the in situ growth. The disadvantage of using radiotracers is that no information is provided on the total amount of carbon that is required to support bacterial production.

Respiration, estimated by oxygen consumption, has been used to examine the bacterial contribution to total community respiration and estimate bacterial growth efficiencies (Hopkinson et al. 1989, Griffith et al. 1990, Jensen et al. 1990). Taking this approach a step further, the initial oxygen utilization rate, if representative of in situ bacterial respiration, can be used to estimate substrate utilization rate. The exhaustion of primary substrate may be indicated by a plateau in the rates of oxygen utilization and biomass production, as has been found with single and mixed substrates (Busch 1958, Schroeder 1968). The sum of biomass carbon produced and carbon equivalents of the oxygen used at the plateau is an estimate of the concentration of the DOC supporting growth. Continuation of the incubation to a final plateau allows calculation of the total biodegradable DOC and, thus, determination of the fraction of the DOC pool that is capable of supporting growth. While oxygen consumption has been related to the growth of marine bacteria and consumption of organic compounds in experiments receiving large additions of organic matter (Bauerfeind 1985), little information is available for indigenous concentrations of organic matter.

The focus of the experiments presented here was to compare bacterial oxygen consumption and biomass production to estimate: (1) the fraction of the DOC pool that supports in situ bacterial growth, (2) the rate at which that fraction was used, and (3) the bacterial growth efficiency on that fraction. Initial incubation experiments demonstrated a strong relationship between bacterial biomass production and respiration. Furthermore, the fraction of total DOM supporting this bacterial activity could be small and consumed within hours. Data from mesocosm experiments designed to examine the coupling of bacterial production and substrate production from phytoplankton indicated rapid exhaustion of labile pools of organic matter, resulting in diel variations in bacterial production and respiration. The growth efficiency of bacteria in the mesocosm experiments varied over the diel cycle and indicated bacteria were less efficient when labile substrate was less abundant. Finally, incubation experiments with water samples from marsh, estuarine and coastal waters demonstrated a large spatial and temporal variation in bacterial growth efficiency. This large variation in growth efficiency suggests that this parameter is an important consideration in estimates of carbon fluxes through microbial assemblages.

\section{MATERIALS AND METHODS}

Sample sites. Water samples were taken from off the dock of the Gulf Breeze Environmental Research Laboratory in Santa Rosa Sound (Florida, USA) and at Range Point, a nearby salt marsh. These sites were sampled frequently between March 1990 and April 1991. The range in temperature and salinity for sample dates in Santa Rosa Sound was 17.2 to $28.5^{\circ} \mathrm{C}$ and 14 to $29 \%$. For Range Point, temperature varied between 14.4 and $28.4^{\circ} \mathrm{C}$ and salinity between 10 and $28 \%$. Also, water samples were taken at maximum high and minimum low tides from the mouths of 5 northwestern Florida estuaries during May 12 to 17, 1992. These estuaries included St. Georges Sound, St. Joe Bay, St. Andrew Bay, Choctawahatchee River and Pensacola Bay. The average high and low tide salinity in the estuaries was $34.9 \pm 0.5 \%$ and $29.1 \pm 4.2 \%$ respectively. The average temperature was $22.4 \pm 0.8^{\circ} \mathrm{C}$. 
Incubation experiments. Water samples were drawn through $1.0 \mu \mathrm{m}$ filter cartridges (Millipore) into sample containers using a peristaltic pump. To minimize the enrichment of DOC pools as an artifact of filtration (Fuhrman \& Bell 1985, Nagata \& Kirchman 1990), water was passed through the filter cartridges using a peristaltic pump at low pump speeds. Back pressures during filtration were less than ca $2 \mathrm{~mm}$ HG. To insure that organic matter did not leach from particles trapped on the filters, filters were not allowed to dry and were changed frequently. Dissolved free amino acid concentrations in water samples before and after filtration were not significantly different (data not shown). Similar precautions have been used successfully by other researchers to prevent enrichment by filtration of bacterial substrate pools (Fuhrman \& Bell 1985, Waterbury et al. 1986, Malone et al. 1991).

Sample containers were glass biological oxygen demand (BOD) bottles in most estuarine samples or $4 \mathrm{l}$ intravenous (IV) bags (Secure, non-DEHP vinyl, MacLean-Fogg Corp.) in the diel mesocosm experiments. Containers were rinsed with $10 \% \mathrm{HCL}$, deionized water and sample water. Replicates for analysis of oxygen concentrations consisted of either triplicate BOD bottles for each subsampling or triplicate IV bags from which 3 samples were drawn $(9$ replicates per time point). The IV bags were filled by dispensing the filtered water through a 3-way manifold. All samples were incubated in the dark. Ambient temperatures were maintained by incubating samples in coolers that were attached to recirculating water baths.

The IV bags were used for the diel incubation experiments because many subsamples could be taken through time without having to fill and incubate numerous bottles. This shortened the amount of time that was required to initiate experiments. Also, the IV bags could be subsampled without introducing oxygen by applying positive pressure on the bags while samples drained through the tubing. We tested the bags for potential toxicity to bacteria by incubating parallel water samples in bags and teflon bottles. Bacterial abundance in the 2 containers was not significantly different through time. Also, we determined the rate of oxygen diffusion across the bag by monitoring the oxygen accumulation in bags initially filled with sterile, deoxygenated deionized water. The oxygen diffusion constant $k$ for the bags was estimated to be $0.015 \mathrm{~h}^{-1}$ using the equation $D_{t}=D_{\mathrm{I}} \mathrm{e}^{k t}$, where $D_{\mathrm{I}}$ is initial oxygen deficit relative to saturation and; $D_{l}$ is deficit at time $t$. When the IV bags were used to measure oxygen utilization, rates were adjusted using this diffusion constant. Diffusion is only significant when the rate of oxygen respiration is low. These bags were adequate for measuring bacterial respiration in metabolically active estuarine waters and the meso- cosm experiments; however, they may not be suitable for work in coastal and oligotrophic waters.

Two different approaches were used for the incubation experiments. Either water samples were passed through $0.2 \mu \mathrm{m}$ cartridge filters (Millipore) and inoculated with a $1 \%$ volume of $1.0 \mu \mathrm{m}$ filtered water or $1.0 \mu \mathrm{m}$ filtered water samples were monitored through time. Filtered water samples that were seeded with $1 \%$ volume of $1.0 \mu \mathrm{m}$ filtered water provided for an examination of bacterial growth responses in the absence of resource limitation (Kirchman et al, 1982). Undiltuted bacterial assemblages in the $1.0 \mu \mathrm{m}$ filtrates were used for estimates of in situ bacterial growth yields. The length of the incubation experiments varied between $6 \mathrm{~h}$ and $20 \mathrm{~d}$. Long incubation times were used to compare the degradation of labile and refractory components of the DOM pool. Shorter incubations, 6 to $24 \mathrm{~h}$, were used to estimate in situ bacterial respiration and production. Incubation times were minimized when possible to reduce the effect of container artifacts (Zobell 1943, Ferguson et al. 1984) on the interpretation of rate data.

Rates of oxygen utilization were measured by monitoring changes in oxygen concentration over time. Generally 8 to 10 subsamples were taken through the course of a 6 to $24 \mathrm{~h}$ experiment. The slope of the initial linear portion of the oxygen concentration to time relationship was used as the hourly consumption rate. Oxygen values indicating a plateau in oxygen utilization were omitted from the calculation.

Oxygen concentration. For the $20 \mathrm{~d}$ incubation experiments, oxygen concentrations were measured with a YSI oxygen probe. The calibration of the probe was checked with oxygen titrations using the Winkler method described by Carpenter (1965). The shorter term incubation experiments required greater precision to measure significant changes in oxygen concentrations. In these experiments, oxygen concentrations were measured by titration using a Brinkman 686 Titroprocessor equipped with a 665 Dosimat titrant pump and a potentiometric probe. The precision for measuring oxygen concentrations was $1.52 \%(n=90)$ and $0.65 \%(n=369)$ in IV bags and BOD bottles respectively.

Bacterial abundance, biomass and production. Bacterial abundance was measured using epifluorescence microscopy as described by Hobbie et al. (1977). Bacterial biovolumes were estimated from projected photomicrographs of the acridine orange preparations. Photomicrographs were calibrated using bead standards. For the July 1991 dock incubation experiment and experiments at the mouths of the 5 northwestern Florida estuaries, bacterial abundance was estimated from bacterial cells stained with 4',6-diamidino-2-phenylindole (DAPI) (Coleman 1980). For these samples, bacterial bio- 
volumes were determined using computer assisted image analysis (Bjørnsen 1986) of DAPI-stained bacteria on a Nikon epifluorescence microscope coupled with an MTI Dage CCD video camera and MSI computer software. The image analysis system was calibrated with $1.17,0.63,0.53$, and $0.46 \mu \mathrm{m}$ diameter blue fluorescent beads (Polysciences, Inc.).

Biovolume data were log-normally distributed. Average biovolumes were calculated from the mean and standard deviation of natural log transformed biovolume data by using the equation:

$$
X=\mathrm{e}^{x+05 S D^{2}}
$$

where $X=$ average biovolume; $x=$ mean of the logtransformed biovolumes; and $\mathrm{SD}=$ standard deviation of the log-transformed biovolumes.

Biovolumes were converted to carbon biomass using data presented by Simon \& Azam (1989). For easy use of their data, the following polynomial equation was used to described the relationship between carbon content and biovolume:

$$
C=6.67+173.9 V-144.1 V^{2} \quad\left(\mathrm{r}^{2}=1.00\right)
$$

where $C=\mathrm{fg}$ Carbon cell ${ }^{-1}$; and $V=$ biovolume cell ${ }^{-1}$

Bacterial production was determined from the change in bacterial carbon with time. The slope of the initial linear portion of the abundance-time relationship was used as the hourly production rate (Wright \& Coffin 1984b).

Mesocosm experiments. The diel incubation experiments were conducted in a $6200 \mathrm{I}$ concrete tank located on the dock at the Gulf Breeze Research Laboratory. Sound water was continuously pumped into the tank, providing a $24 \mathrm{~h}$ water retention time. The intention of this experimental design was to provide a relatively consistent water mass without depleting carbon and nutrients. Because the residence time of a contained water mass is an exponential function of the retention time, the inflow water had little effect on the microbial activity within the tank. Nitrogen and phosphorus were added as $\mathrm{NH}_{4} \mathrm{Cl}$ and $\mathrm{K}_{2} \mathrm{HPO}_{4}$ at 10 and $2 \mu \mathrm{M}$. In addition, nutrients were supplemented with a peristaltic pump to maintain these concentrations in incoming soundwater. The mesocosm was set up with running water and nutrient enrichment 3 to $4 \mathrm{~d}$ prior to the start of the experiments. Experiments were conducted in June and July 1991 for 36 and 48 h, respectively. Subsamples were taken for oxygen consumption and bacterial cell production every $4 \mathrm{~h}$. These experiments were set up in triplicate IV bags as was described above with $1.0 \mu \mathrm{m}$ filtered water Oxygen concentrations and bacterial abundance and biomass were measured at $0.5 \mathrm{~h}$ intervals for $3 \mathrm{~h}$ and then at 4 and $6 \mathrm{~h}$. In addition, the tank was sampled at the beginning of every incubation experiment for $\mathrm{DOC}, \mathrm{PC} / \mathrm{PN}$ and bacterial abundance.

Dissolved and particulate organic matter. Samples for DOC analysis were filtered through Whatman GF/F filters (baked $500^{\circ} \mathrm{C}$ for $4 \mathrm{~h}$ ). Filtrate was sealed in baked glass ampules and frozen at $-80^{\circ} \mathrm{C}$. DOC concentrations were measured using a Shimadzu 5000 TOC analyzer (high temperature, platinum catalyst).

Particulate carbon and nitrogen concentrations were measured on baked $13 \mathrm{~mm} \mathrm{GF/F}$ filters using a CarloErba NA1400 analyzer.

Preparation of substrate for enrichment experiments. Cyclotella sp. was grown on IMR media. When cultures reached stationary phase growth, cells were filtered onto $G F / F$ filters and rinsed in sterile saline water. Cells were broken open with a tissue grinder and cellular and filter debris were removed by first centrifugation and then filtration through GF/F filters. Spartina alterniflora leaves were rinsed with sterile saline and crushed using a tissue grinder. Cell debris
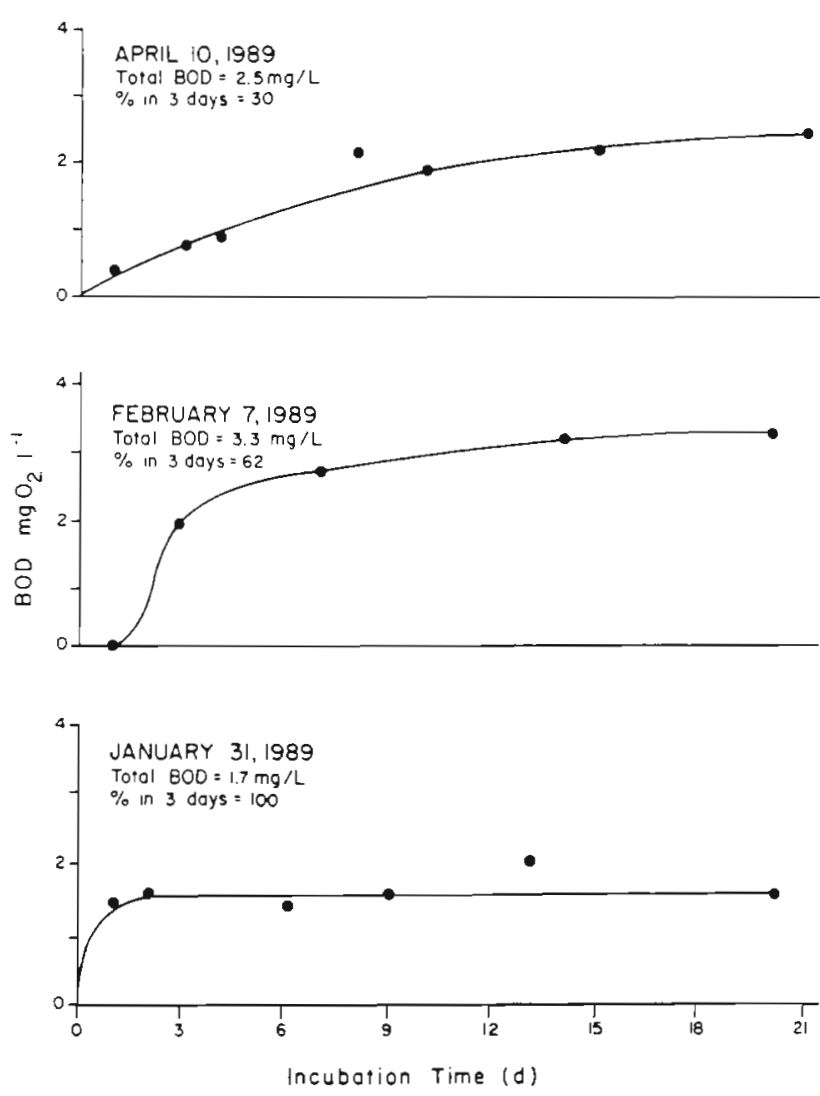

Fig. 1. Twenty day biological oxygen demand (BOD) experiments conducted between January 31 and April 10, 1989, with waters from Santa Rosa Sound. Water samples were filtered through $0.2 \mu \mathrm{m}$ filters and inoculated with $1 \% 1.0 \mu \mathrm{m}$ filtered water. Samples were incubated in triplicate glass buttles in the dark at room temperature 
was removed using centrifugation and filtration. Concentrates of organic matter were stored frozen at $-20^{\circ} \mathrm{C}$. Prior to use concentrates were thawed and filtered. Additions were based on DOC concentrations after the final filtration.

\section{RESULTS AND DISCUSSION}

\section{Bacterial utilization of DOC}

Initial experiments were designed to study the appropriate time scale and sensitivity of oxygen consumption as a method for the analysis of bacterial carbon utilization. To examine the amount and rate of substrate degradation, BOD experiments were conducted with waters from Santa Rosa Sound between January 31 and April 10, 1989. The pattern for oxygen utilization over time was substantially different among the sample dates (Fig. 1). While the ultimate BOD and, thus, total degradable organic matter was similar for all sample dates, the rate of oxygen consumption was
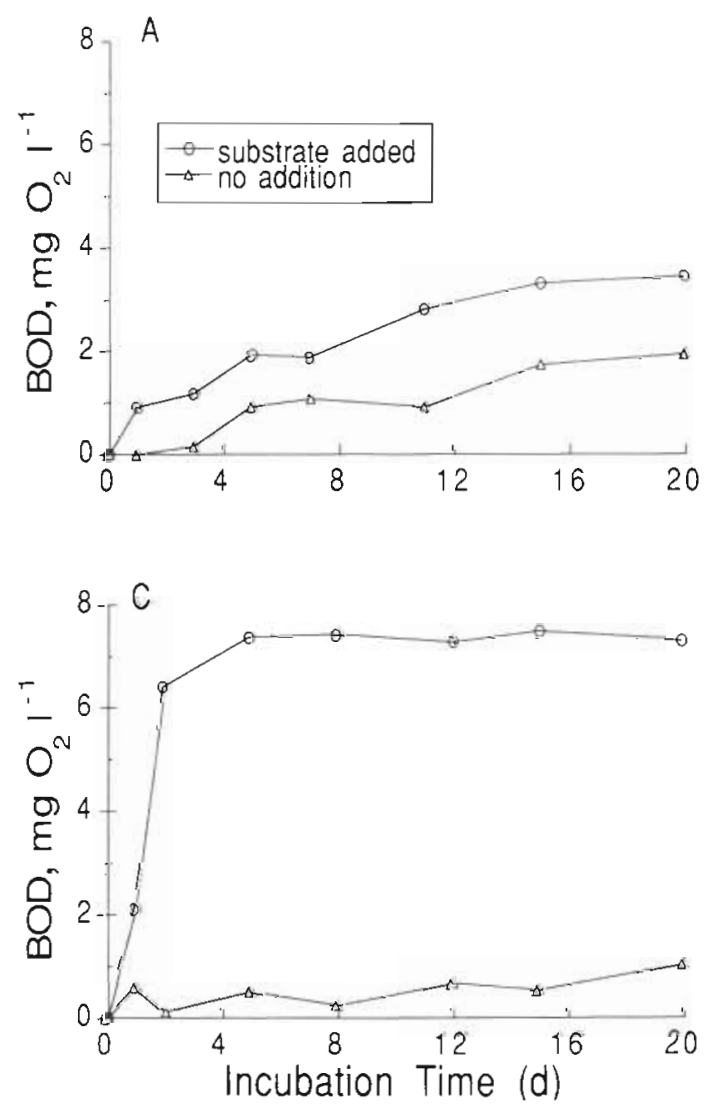

markedly different. On January 31 and February 7, a rapid increase in the $B O D$ was observed over the first 2 to $3 \mathrm{~d}$ of the experiment. The BOD was substantially smaller for the remainder of the experiment. In contrast, on April 10, the initial oxygen utilization was much slower. These examples demonstrate that bacterial activity is not well correlated with total substrate concentration (i.e. the total degradable organic matter as measured by the ultimate BOD). They suggest that substrate composition is important and that when labile compounds are available much greater activity occurs.

The effect of substrate additions on bacterial oxygen consumption was studied by supplementing Santa Rosa Sound water with dissolved organic matter from Cyclotella sp. or Spartina alterniflora (Fig. 2). Additions of carbon from Cyclotella sp. at $1 \mathrm{mg} \mathrm{Cl}^{-1}$ (Fig. 2A) and $0.78 \mathrm{mg} \mathrm{C}^{-1}$ (Fig. 2B) resulted in significantly greater BOD than observed in unamended samples. The addition of $10 \mathrm{mg} \mathrm{C}^{-1}$ of dissolved organic matter from $S$. alterniflora created a large oxygen demand that nearly exhausted dissolved oxygen within $2 \mathrm{~d}$ (Fig. 2C). The BOD values associated with the added substrate
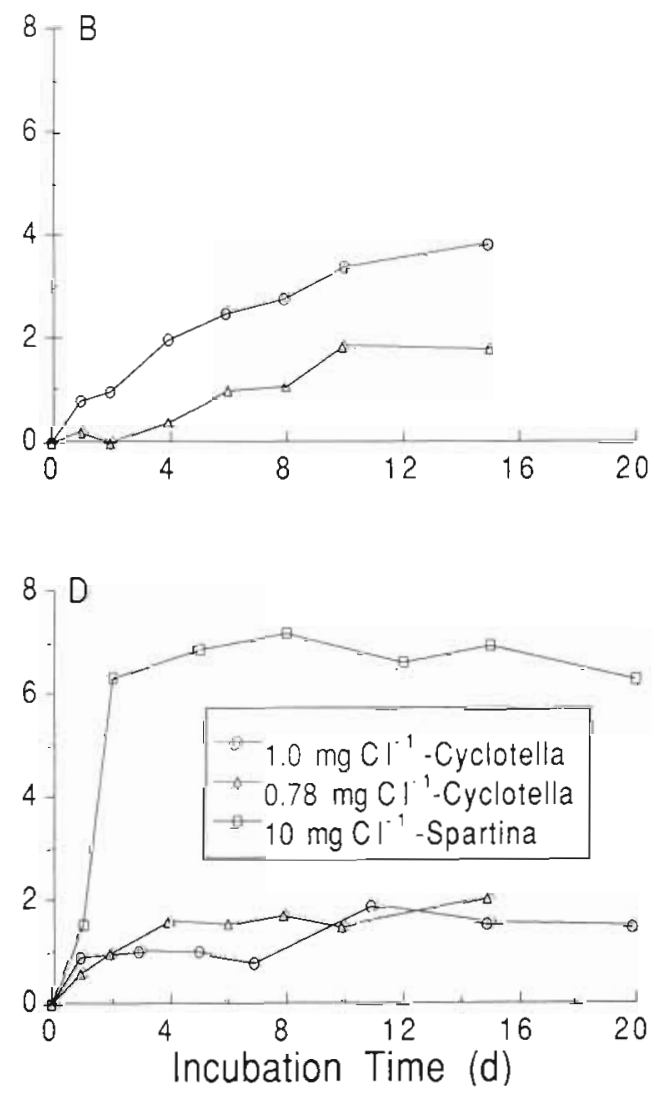

Fig. 2. BOD measured on water samples from Santa Rosa Sound that were enriched with leachate from Cyclotella sp. or Spartina alterniflora. (A) $1 \mathrm{mg} \mathrm{C} \mathrm{l}^{-1}$ Cyclotella leachate; (B) $0.78 \mathrm{mg} \mathrm{C} \mathrm{l}^{-1}$ Cyclotella leachate; (C) $10 \mathrm{mg} \mathrm{C}^{-1}$ Spartina leachate; and (D) BOD resulting from the addition of substrate (the difference between the amended and control samples). Water for all experiments was filtered through $0.2 \mu \mathrm{m}$ filters and inoculated with $1.0 \mu \mathrm{m}$ filtered water $(1 \%$ addition $)$. Samples were incubated in triplicate BOD bottles in the dark at room temperature 
(i.e. the difference between the BOD values observed in the enriched and unamended samples) are shown in Fig. 2D. In contrast to BOD values for the untreated samples, which increased throughout the 15 to $20 \mathrm{~d}$ experiments, the added substrate BOD values were essentially complete within the first few days.

Significant oxygen consumption within the first 24 to $48 \mathrm{~h}$ of unamended water sample incubations and complete utilization of added labile substrate within the same period suggest that short time scale experiments are required to study bacterial utilization of DOC. Long incubation experiments that exceed the supply of labile substrate could significantly underestimate bacterial growth and activity. To determine more appropriate time scales for these experiments, oxygen utilization was compared in water samples incubated

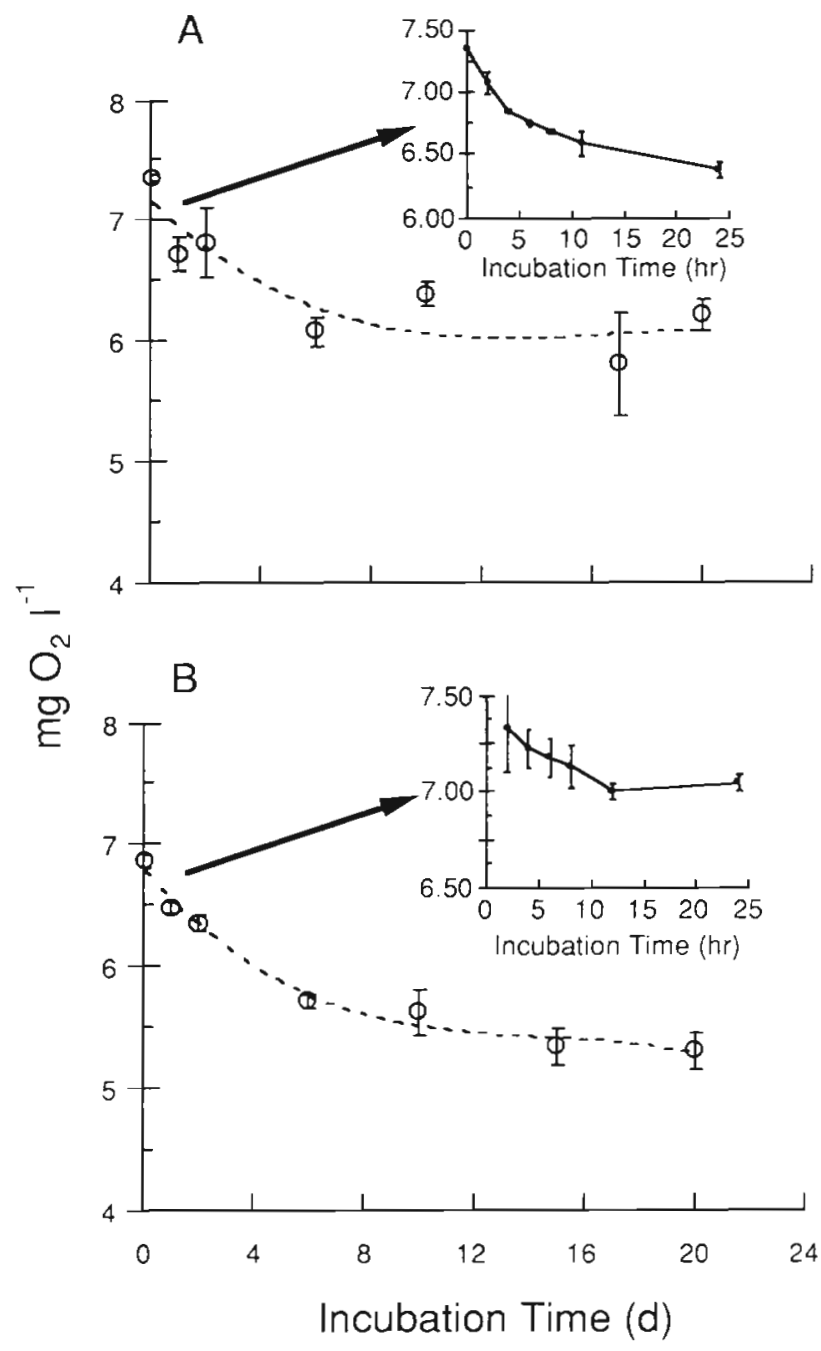

Fig. 3. Comparison of oxygen concentrations in BOD bottles over $20 \mathrm{~d}$ experiments with oxygen concentrations in IV bags for $24 \mathrm{~h}$. Water samples from Santa Rosa Sound were filtered through $1.0 \mu \mathrm{m}$ filters and incubated in the dark at room temperature. (A) August 7, 1990; (B) September 25, 1990 in IV bags for $24 \mathrm{~h}$ and BOD bottles for $20 \mathrm{~d}$ (Fig. 3). In 2 experiments, the most rapid oxygen utilization was observed within the first $10 \mathrm{~h}$. After this time, a significant decline in utilization rates occurred, particularly in the September 25 sample, in which the oxygen concentration did not change between 12 and $24 \mathrm{~h}$. A slow rate of oxygen utilization was observed for the remainder of the $20 \mathrm{~d}$ experiments.

In subsequent experiments, changes in bacterial abundance were compared with respiration during 24 to $30 \mathrm{~h}$ incubation experiments. The maximum rate of oxygen utilization in samples from Range Point and Santa Rosa Sound occurred between 2 and $11 \mathrm{~h}$ (Fig. 4). Similarly, increases of bacterial abundance were most rapid during the first $11 \mathrm{~h}$ of the experiment. After $11 \mathrm{~h}$, rates of oxygen utilization and cell production were lower.

The experiments described above demonstrate that bacteria may grow on a small pool of organic matter that is rapidly consumed. Rapid turnover of small, labile fractions of the total DOC pool has been observed using other approaches for measuring carbon turnover. For example, radiotracer experiments have been used to demonstrate that dissolved free amino acid pool turnover times can be less than 1 h (Fuhrman \& Ferguson 1986, Fuhrman 1987). These labile components of the bulk DOC may support a significant proportion of bacterial production. In a recent study that compared bacterial assimilation of dissolved amino acids and nucleic acids it was found that dissolved free amino acids supported 42 to $91 \%$ of the total bacterial carbon demand (Jørgensen et al. 1993).

Fractionation of DOC according to molecular weight has been another approach for examining bacterial availability of carbon pools within bulk DOC (Meyer et al. 1987, Tranvik 1990, Sundh 1992). Researchers studying DOC size fractions in aquatic environments have found that the $<10^{3}$ dalton component supports the majority of bacterial activity (Meyer et al. 1987, Sundh 1992). Bacteria appear to metabolize more complex, higher molecular weight material only after the smaller molecular weight component is consumed. These observations were applied in a recent modeling study, for which substrate control on bacterial populations was examined using a formulation that consisted of 3 carbon pools. These pools included labile compounds that are readily used by bacteria, a pool comprised of more complex compounds that are used at slower rates and a refractory pool that bacteria generally do not metabolize (Connolly et al. 1992). A primary assumption of this model was that bacteria preferentially exhaust the labile components of the substrate pool prior to consuming the more complex and refractory compounds. Our data support this assumption. Characteristically, oxygen consumption and bacterial production were fastest 


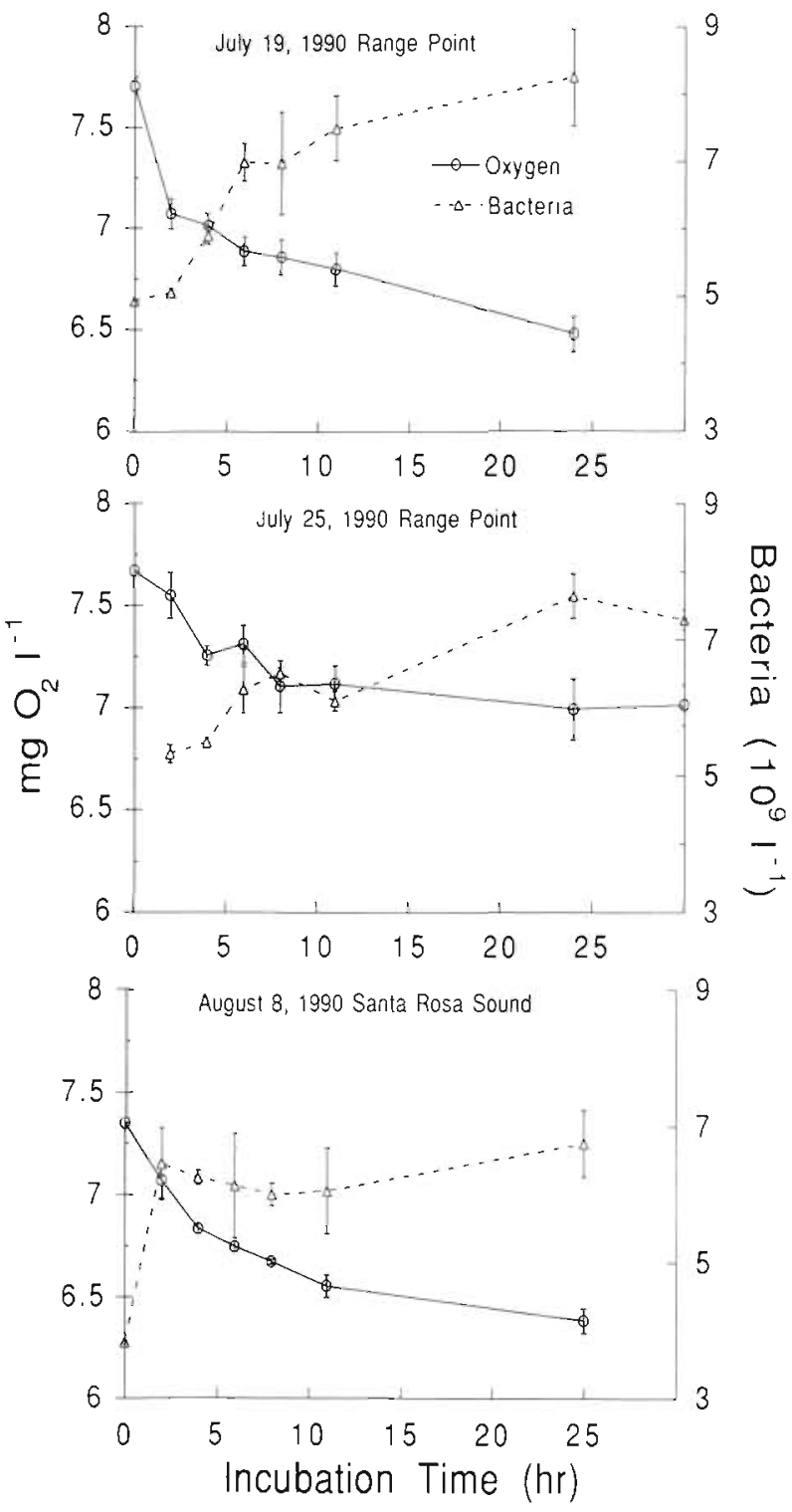

Fig. 4. Bacterial abundance and oxygen concentrations in IV bag incubation experiments over 24 to $30 \mathrm{~h}$. Water samples were filtered through $1.0 \mu \mathrm{m}$ filters and incubated at ambient temperatures. Samples were taken from Range Point on July 19 and 25, 1990, and Santa Rosa Sound on August 8, 1990

through the first 6 to $12 \mathrm{~h}$ of the incubation experiments. Although slower metabolism of complex and refractory compounds may occur simultaneously, the total flux from more recalcitrant carbon through the bacterial assemblage does not appear to be significant relative to the labile pool. However, to understand the significance of the carbon flux of recalcitrant material through microbial food webs, the spatial and temporal dynamics of labile carbon sources must be defined.

The salient observations of these preliminary experiments were: (1) bacterial growth can be supported by a small labile fraction of the total DOC, and (2) bacterial production rate and amount of biomass produced in incubation experiments varied with assumed changes in substrate quality and nutrient availability. As a result of these observations, experiments were designed to address the following questions: (1) If small labile components of total DOC support bacterial growth, how closely coupled are bacteria with substrate sources and how does this coupling affect bacterial production? (2) What is the temporal and spatial variation in the growth efficiency of the bacterial assemblage? (3) What fraction of the DOC pool is turned over by bacteria? These topics are addressed in the following sections.

\section{Bacterial coupling to sources of substrate}

To examine bacterial coupling to organic matter from phytoplankton, mesocosm experiments were conducted over 32 and $48 \mathrm{~h}$ time periods in June and July 1991 respectively (see 'Materials and methods'). Particulate carbon and nitrogen were measured in the mesocosm through the course of the experiments as an indicator of planktonic biomass. Particulate carbon (PC) in the June and July mesocosm experiments peaked at mid-day and gradually declined to mid-evening; lowest values were measured at night (Fig. 5). The ranges of particulate carbon concentrations were 103 to 245 and 48.4 to $93.6 \mu \mathrm{m} \mathrm{C}^{-1}$ for the July and June experiments respectively. Particulate nitrogen (PN) followed a similar diel cycle, with the exception of the second day of the July experiment (Fig 5). The ranges in particulate nitrogen concentrations were 18.3 to 47.4 and 10.1 to $17.3 \mu \mathrm{m} \mathrm{N}^{-1}$ for the July and June experiments respectively. The lowered particulate carbon and nitrogen concentrations during the second day of the July experiment were attributed to heavy cloud cover and afternoon thunder showers. The effect of the clouds and rain were observed in the other microbial parameters that are discussed below. Carbon/nitrogen ratios of particulate matter ( $\mathrm{PC} / \mathrm{PN}$ ) varied between 4.5 and 7 through the diel cycles, and peaked in the late afternoon to early evening (Fig. 5). Similar ratios and trends were observed for both experiments. The bacterial contribution to the particulate matter, based on averaged biovolumes and appropriate conversion factors, ranged from 30 to $48 \%$ and 14 to $48 \%$ for the June and July experiments respectively. For each experiment the greatest bacterial contribution to particulate carbon was at night. The range in the $\mathrm{C} / \mathrm{N}$ ratio is thought to result from the variation in phytoplankton production over the diel cycle. Changes in oxygen concentration in the mesocosm support this observation (data not shown).

Bacterial production and oxygen consumption were closely coupled to the trends for particulate carbon and nitrogen. For both experiments, maxima in bacterial 

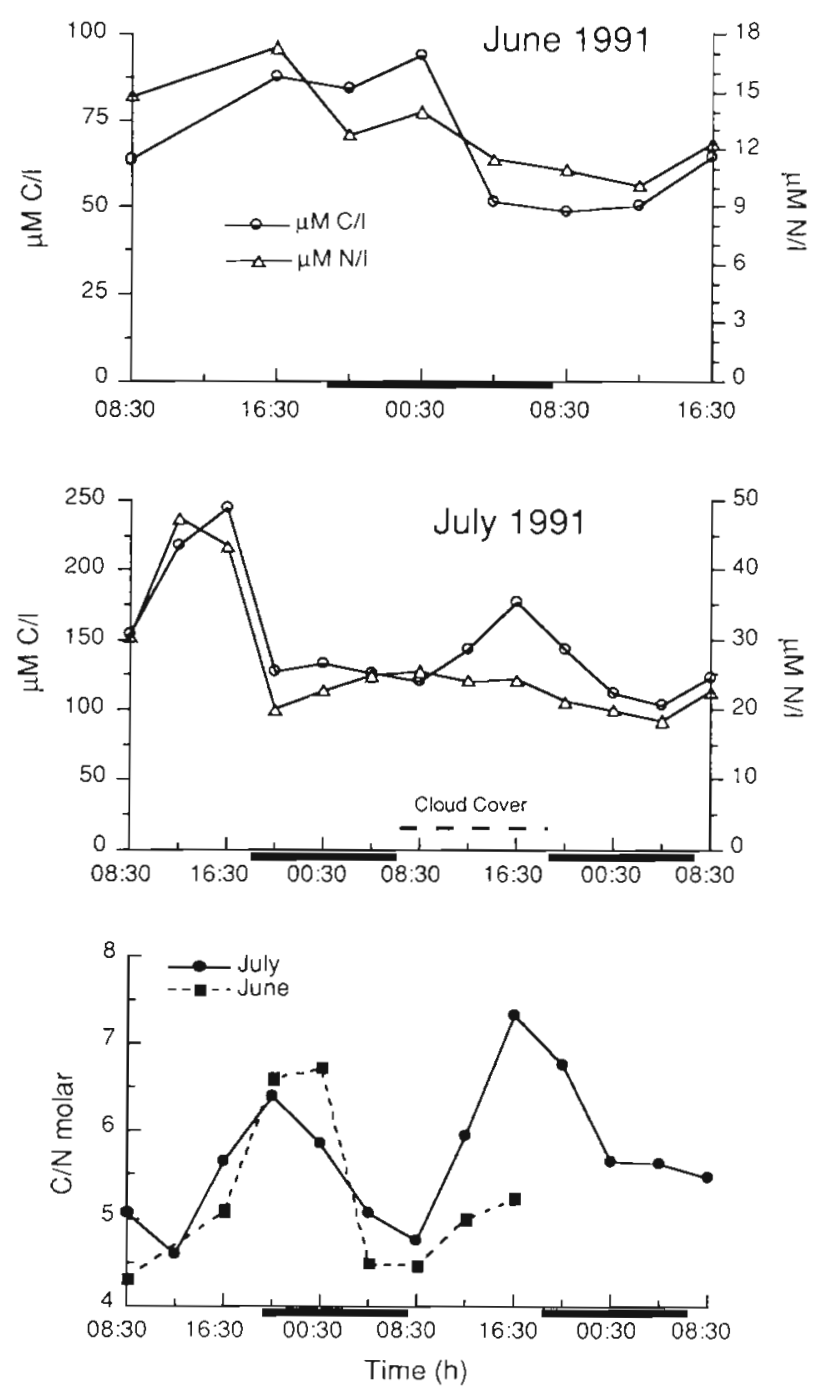

Fig. 5. Particulate carbon and particulate nitrogen concentrations and molar carbon/nitrogen ratios from mesocosm experiments conducted on the dock at the Gulf Breeze Environmental Research Laboratory in June and July 1991. Heavy horizontal bars indicate periods of darkness

production and respiration were observed during daylight and early evening and minima were measured at night and early morning (Fig. 6). Variations in production and respiration were closely coupled. The diel ranges in bacterial cell production for the June and July experiments were 0.09 to $0.47 \times 10^{9}$ and 0.51 to $3.36 \times 10^{9}$ cells $1^{-1} \mathrm{~h}^{-1}$ respectively. The diel range in oxygen consumption for the June experiment was 13 to $294 \mu \mathrm{g} \mathrm{O}_{2} \mathrm{l}^{-1} \mathrm{~h}^{-1}$ and for the July experiment 38 to $209 \mu \mathrm{g} \mathrm{O}_{2} \mathrm{l}^{-1} \mathrm{~h}^{-1}$. Bacterial cell production and oxygen consumption were lower during the second day of the July experiment.

Comparisons of bacterial growth and oxygen consumption in water samples collected at 08:30 and
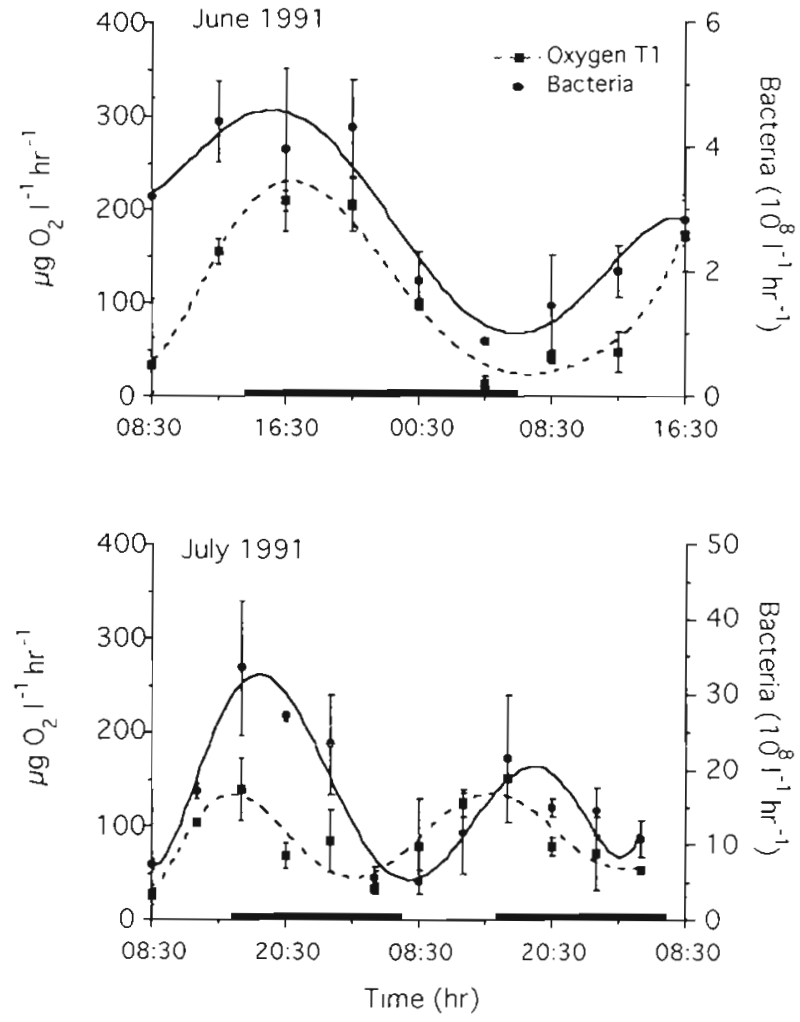

Fig. 6. Bacterial production and oxygen consumption from mesocosm experiments conducted on the dock at the Gulf Breeze Environmental Research Laboratory in June and July 1991. Heavy horizontal bars indicate periods of darkness

16:30 $\mathrm{h}$ for the June and July experiments illustrate the magnitude of the diel range in bacterial activity (Fig. 7). For both experiments, bacterial growth and oxygen consumption were substantially lower in the morning than the afternoon. At 08:30 h oxygen consumption over the $6 \mathrm{~h}$ incubation experiments was 0.27 and $0.24 \mathrm{mg} \mathrm{O}_{2} \mathrm{l}^{-1}$ for June and July respectively. The analogous increase in bacterial concentrations,

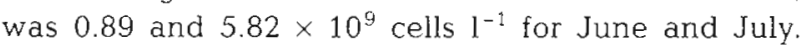
At $16: 30 \mathrm{~h}$ the loss of oxygen was 1.85 and $1.36 \mathrm{mg}$ $\mathrm{O}_{2} 1^{-1}$ and increase in bacterial cells was 1.70 and

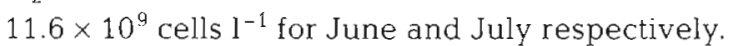

These mesocosm experiments demonstrated that there was large variation in the availability of organic matter that supported bacterial production over diel cycles. The supply of organic matter for bacteria coincided with diel variation in particulate carbon and nitrogen. Particulate carbon and nitrogen ratios and oxygen concentration in the mesocosm suggest that phytoplankton biomass and activity varied through the daily cycles. We observed highest concentrations of particulate carbon and nitrogen during daylight with PC/PN ratios of approximately 7 , near the theoretical Redfield value for phytoplankton. At night the 

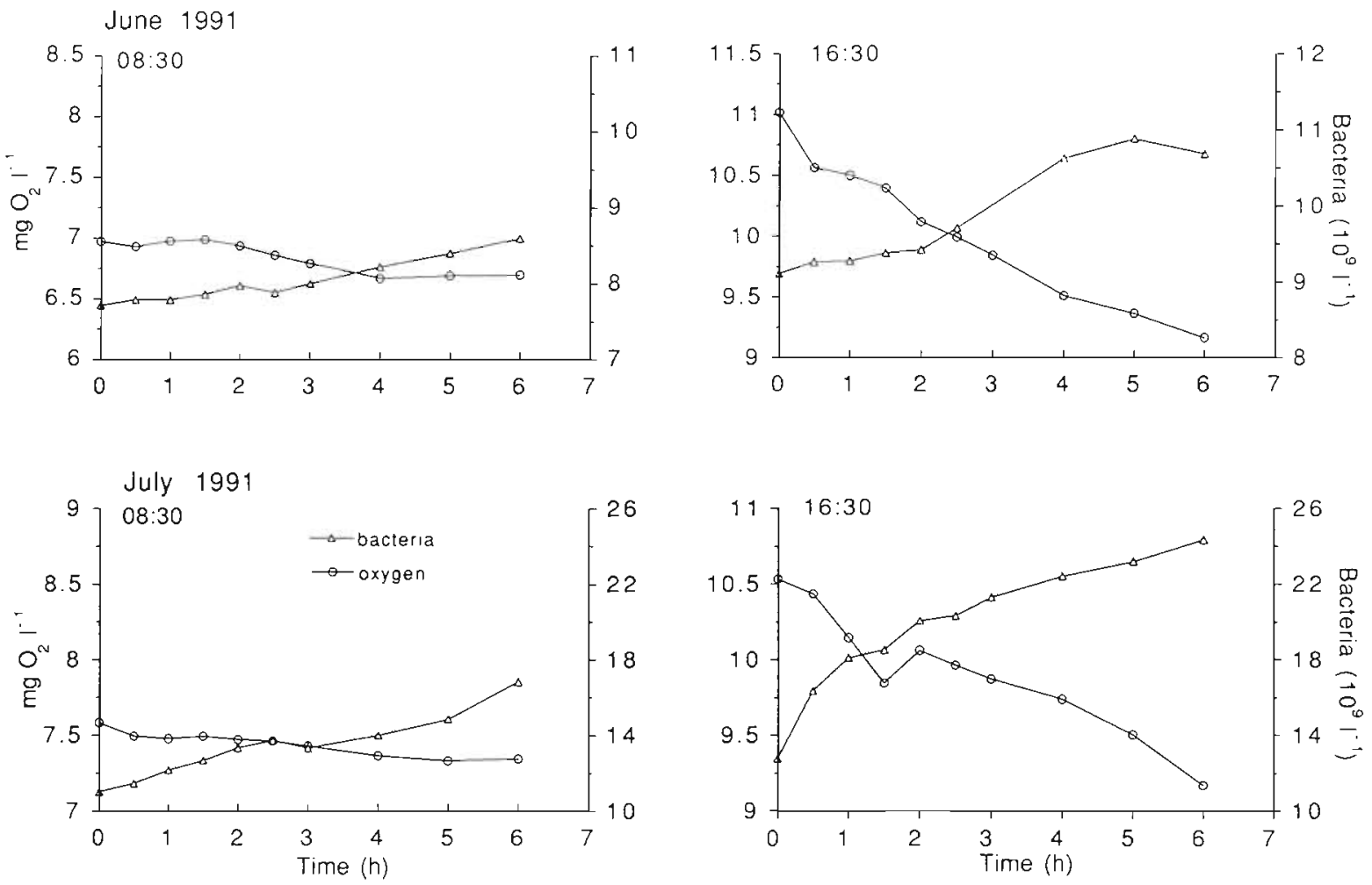

Fig. 7. Changes in bacterial abundance and oxygen concentration over 6 h experiments with water from the June and July diel experiments. Parameters are contrasted at 08:30 and 16:30 h

low PC/PN values, between 4.5 and 5, were more typical of bacteria and protists (Lee \& Fuhrman 1987, Stroeker \& Cappuzo 1990). The large diel variation in bacterial production and oxygen consumption indicated a close coupling between bacteria and phytoplankton.

Diel cycles in phytoplankton production have been demonstrated to be an important factor for short term control of microbial activity. In a study in the Southern California Bight, significantly higher primary production, chlorophyll b concentrations, bacteria biomass and production were measured during daylight (Fuhrman et al. 1985). In several coastal and open ocean environments strong diel variation was noted in microflagellate grazing rates with highest values measured during the daylight (Wikner et al. 1990). However, other studies report microbial activities show little or no variation over diel cycles (Riemann \& Søndergaard 1984, Riemann et al. 1984). The reason for this apparent discrepancy may lie in the source of organic matter that fuels bacterial growth. In ecosystems that are supported by phytoplankton production, diel variation is expected, whereas in estuarine and coastal waters that receive significant amounts of organic matter transported from marshes or upland sources, a strong coupling to diel periodicity may not exist. When a strong diel variation in microbial rates is possible it is important to make appropriate consideration for estimates of carbon budgets.

\section{Bacterial growth efficiency}

A large range in bacterial growth and respiration rates in our preliminary incubation experiments suggested the potential for substantial variation in bacterial growth efficiencies. We conducted experiments to measure bacterial growth efficiency in the July mesocosm experiment, in Santa Rosa Sound and Range Point salt marsh over a long seasonal period, and at the mouths of 5 northwestern Florida estuaries at high and low tide. These data provide a significant data base to examine variations in bacterial growth efficiencies.

Bacterial growth efficiencies were estimated using measurements of bacterial particulate carbon production and oxygen consumption. Bacterial carbon production was generally higher in samples from Range Point than those from Santa Rosa Sound or the mouths of the 5 estuaries. Values for Santa Rosa Sound and the estuaries ranged from 0.02 to $4.6 \mu \mathrm{g} \mathrm{Cl}^{-1} \mathrm{~h}^{-1}$, and from 0 to $18.2 \mu \mathrm{g} \mathrm{C}^{-1} \mathrm{~h}^{-1}$ for Range Point (Table 1). These 
Table 1 Bacterial growth efficiencies measured from production and respuration in incubation experiments from Santa Rosa Sound, Range Point and 5 northwestern Florida estuanes

\begin{tabular}{|c|c|c|c|c|}
\hline Location/Date & $\begin{array}{l}\text { Production } \\
\left(g \subset \mathrm{I}^{-1} \mathrm{~h}^{-1}\right)\end{array}$ & $\begin{array}{c}\text { Respiration } \\
\left(\mu \mathrm{g} \mathrm{O}_{2} \mathrm{l}^{-1} \mathrm{~h}^{-1}\right)\end{array}$ & 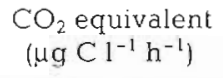 & $\begin{array}{c}\text { Efficiency } \\
(\%)\end{array}$ \\
\hline \multicolumn{5}{|l|}{ Santa Rosa Sound } \\
\hline Mar 7, 1990 & 3.5 & 48.1 & 18.0 & 16 \\
\hline Mar 9, 1990 & 1.2 & 6.0 & 2.3 & 35 \\
\hline Apr 10, 1990 & 2.5 & 15.0 & 5.6 & 31 \\
\hline Apr 25,1990 & 1.1 & 16.1 & 6.0 & 15 \\
\hline Aug 7,1990 & $4.0 \pm 1.4$ & $61.4 \pm 5.2$ & 22.6 & 15 \\
\hline Sep 25, 1990 & $3.2 \pm 4.1$ & 24.9 & 9.2 & 26 \\
\hline Oct 23,1990 & $4.3 \pm 3.6$ & $194.7 \pm 10.6$ & 64.8 & 5.6 \\
\hline Nov 15,1990 & $3.3 \pm 2.0$ & $78.1 \pm 19.0$ & 28.8 & 10 \\
\hline Dec 18,1990 & 0.02 & 12.7 & 4.7 & 0.4 \\
\hline Apr 22,1991 & $0.6 \pm 0.7$ & $65.0 \pm 37.0$ & 24.4 & 2.3 \\
\hline \multicolumn{5}{|l|}{ Range Point salt marsh } \\
\hline Mar 13,1990 & 5.5 & 15.1 & 5.6 & 49 \\
\hline Mar 19,1990 & 0 & 25.1 & 9.4 & - \\
\hline Apr 2, 1990 & 3.4 & 9.5 & 3.6 & 49 \\
\hline Jun 25,1990 & $11.2 \pm 2.0$ & $60.9 \pm 9.8$ & 22.4 & 33 \\
\hline Jul 19,1990 & $18.2 \pm 2.3$ & $127.6 \pm 9.9$ & 47.0 & 28 \\
\hline Aug 28,1990 & $1.1 \pm 0.8$ & 0 & 0 & - \\
\hline Jan 15,1991 & $15.5 \pm 5.1$ & 30.0 & 11.0 & 58 \\
\hline \multicolumn{5}{|l|}{ Northwest Florida estuaries } \\
\hline St. George Sound - High & 1.6 & 10.0 & 3.3 & 33 \\
\hline St. George Sound - Low & 3.9 & 7.6 & 2.5 & 61 \\
\hline St. Joe Bay - High & 4.6 & 15.6 & 5.2 & 47 \\
\hline St. Andrews Bay - High & 3.3 & 7.0 & 2.3 & 59 \\
\hline St. Andrews Bay - Low & 0.8 & 2.7 & 0.9 & 47 \\
\hline Choctawahatchee River - High & 0.3 & 7.5 & 2.5 & 11 \\
\hline Choctawahatchee River - Low & 1.1 & 2.2 & 0.7 & 60 \\
\hline Pensacola Bay - High & 0.6 & 7.7 & 2.6 & 19 \\
\hline Pensacola Bay - Low & 2.5 & 19.7 & 6.6 & 28 \\
\hline
\end{tabular}

values are comparable to estimates of bacterial carbon production reported for other estuarine and coastal systems, which vary between nearly 0 and $17 \mu \mathrm{g} \mathrm{C} \mathrm{l^{-1 }}$ $\mathrm{h}^{-1}$ (Coffin \& Sharp 1987 and references therein, Cole et al. 1988 and references therein). The bacterial production measurements during the July mesocosm

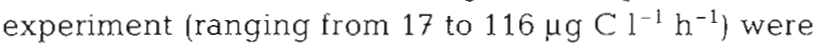
substantially higher than values reported in the literature (Table 2). Bacterial respiration in Santa Rosa Sound and the Range Point Marsh ranged from nearly 0 to $195 \mu \mathrm{g} \mathrm{O}_{2} \mathrm{l}^{-1} \mathrm{~h}^{-1}$; generally values were higher in Santa Rosa Sound (Table 1). Values during the July mesocosm experiment were similar, ranging from 27 to $152 \mu \mathrm{g} \mathrm{O}_{2} \mathrm{l}^{-1} \mathrm{~h}^{-1}$ (Table 2). Respiration was substantially lower at the mouths of the northwestern Florida estuaries, from 0 to $19.7 \mu \mathrm{g} \mathrm{O}_{2} \mathrm{l}^{-1} \mathrm{~h}^{-1}$ (Table 1). Reported values of pelagic community respiration range from 1 to $292 \mu \mathrm{g} \mathrm{O}_{2} \mathrm{l}^{-1} \mathrm{~h}^{-1}$, with coastal values between 1 and $30 \mu \mathrm{g} \mathrm{O}_{2} \mathrm{l}^{-1} \mathrm{~h}^{-1}$ and estuarine values typically from 4 to $80 \mu \mathrm{g} \mathrm{O}_{2} \mathrm{l}^{-1} \mathrm{~h}^{-1}$ (Hopkinson 1985 and references therein, Hopkinson et al. 1989).
Bacterial growth efficiencies $(Y)$ were calculated as:

$$
Y=\Delta B /(\Delta B+R) \times 100
$$

where $\Delta B=$ change in bacterial biomass; and $R=$ $\mathrm{CO}_{2}$ production rate calculated from the oxygen consumption during the incubation experiments. A respiratory quotient of 1 is assumed for these calculations. The range of growth efficiencies for Santa Rosa Sound was 0.4 to $35 \%$ and the average was $16 \%$ (Table 1). For northwestern Florida estuaries at high and low tide, growth efficiencies ranged from 11 to $60 \%$ and averaged $41 \%$. Similarly, at Range Point growth efficiencies ranged from 28 to $58 \%$ and averaged $43 \%$ (Table 1). Growth efficiencies for the July mesocosm experiment were higher, ranging from 37 to $79 \%$ and averaging $63 \%$ (Table 2). These averaged growth efficiencies are in the range of values that are reported for other ecosystems. At the high range of efficiencies is $42 \%$ for the Roskilde Fjord, Denmark (Jensen et al 1990) and 40\% for the Southern Ocean (Bjørnsen \& Kuparinen 1991). How- 
Table 2. Bacterial growth efficiencies measured from production and respiration ( $\pm \mathrm{SD}$ ) in incubations from the July mesocosm experiments. Average efficiency: $63 \%$

\begin{tabular}{|ccccc|}
\hline Time $(\mathrm{h})$ & $\begin{array}{c}\text { Production } \\
\left(\mu \mathrm{g} \mathrm{Cl} \mathrm{l}^{-1} \mathrm{~h}^{-1}\right)\end{array}$ & $\begin{array}{c}\text { Respiration } \\
\left(\mu \mathrm{g} \mathrm{O}_{2} \mathrm{I}^{-1} \mathrm{~h}^{-1}\right)\end{array}$ & $\begin{array}{c}\mathrm{CO}_{2} \text { equiv. } \\
\left(\mu \mathrm{CO}_{2} \mathrm{I}^{-1} \mathrm{~h}^{-1}\right)\end{array}$ & $\begin{array}{c}\text { Efficiency } \\
(\%)\end{array}$ \\
\hline $08: 30$ & $26 \pm 2.3$ & $27 \pm 11$ & 10 & 72 \\
$12: 30$ & $59 \pm 3.2$ & $104 \pm 2$ & 38 & 61 \\
$16: 30$ & $115 \pm 27$ & $140 \pm 33$ & 51 & 69 \\
$20: 30$ & $94 \pm 18$ & $69 \pm 14$ & 25 & 79 \\
$00: 30$ & $80 \pm 20$ & $85 \pm 34$ & 31 & 72 \\
$04: 30$ & $20 \pm 4.3$ & $34 \pm 6$ & 12 & 62 \\
$08: 30$ & $17 \pm 5.1$ & $79 \pm 50$ & 29 & 37 \\
$12: 30$ & $40 \pm 17$ & $125 \pm 14$ & 46 & 47 \\
$16: 30$ & $74 \pm 26$ & $152 \pm 20$ & 56 & 57 \\
$20: 30$ & $51 \pm 3.9$ & $79 \pm 10$ & 29 & 64 \\
$00: 30$ & $50 \pm 9.6$ & $71 \pm 40$ & 26 & 66 \\
$04: 30$ & $37 \pm 7.4$ & $53 \pm 4$ & 19 & 66 \\
& & & & \\
\hline
\end{tabular}

efficiency. As discussed above, the diel variation in oxygen consumption and bacterial production indicated that bacteria were substrate limited during the late evening and early morning. Bacterial growth efficiencies corresponded to the apparent substrate supply in the July mesocosm experiment (Fig 8). During the daylight and early evening when substrate availability and bacterial growth were highest the growth efficiencies were highest. This result is consistent with the hypothesis that the ultimate bacterial role in the microbial food chain is a function of the supply of organic matter (Wright et al. 1987). Under substrate limitation bacteria grow less efficiently because a greater percentage of substrate is respired to sup-

ever, considerably lower growth efficiencies have been reported in other studies. In the North Atlantic Ocean, carbon growth efficiencies ranged from 1.6 to 9.0\% (Kirchman et al. 1991). Growth efficiencies near $0 \%$ are reported for the Grand Banks, Newfoundland, Canada (Smith et al. 1986). In our study, growth efficiencies were generally largest in the environments with highest bacterial activity. This observation is consistent with the findings of a recent study in which growth efficiencies ranged from 11 to $2 \%$ from estuarine to open ocean waters across the Georgia continental shelf (Griffith et al. 1990). The large variation in growth efficiencies estimated here and reported in other studies suggests that this could be a sensitive parameter when examining the bacterial role in carbon fluxes through microbial food chains.

Our mesocosm experiments provide information on the impact of substrate limitation to bacterial growth

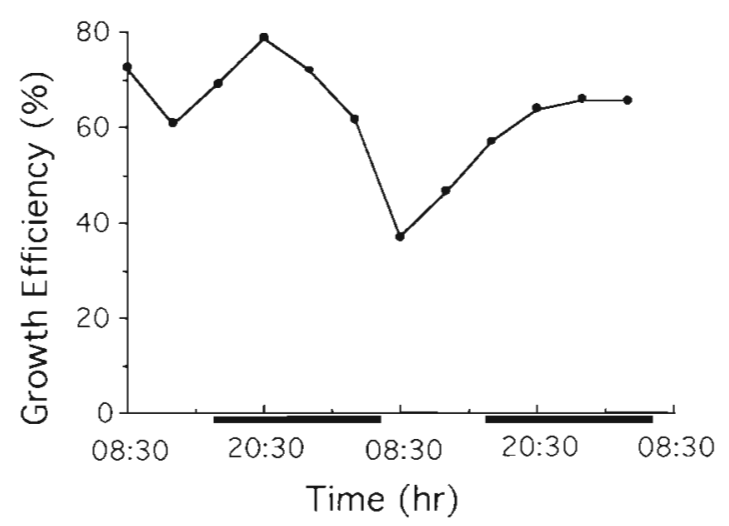

Fig. 8. Diel variation in bacterial growth efficiency calculated from bacterial carbon production and oxygen consumption for the July diel experiment. Heavy horizontal bars indicate periods of darkness port cellular maintenance energy. With sufficient substrate, more energy is built into particulate carbon and more biomass is available to bacterial predators. Nutrient availability can also control the efficiency of bacterial growth on organic matter. Hopkinson et al. (1989) have suggested that bacterial growth efficiencies are higher when substrates are nitrogen rich. In the Perdido Estuary, Florida, additions of ammonium to indigenous bacterial assemblages ranging from 0 to $2 \mu \mathrm{M}$ showed a positive, significant correlation with the growth yield (Kroer in press). The relative control of carbon and nutrient limitation on growth efficiency in our study is not known. The dynamics of carbon and nutrients in controlling bacterial growth in aquatic environments are complex (e.g. Kirchman 1990) and warrant further investigation.

\section{Turnover of DOC by bacteria}

With measurements of bacterial production and growth efficiency, an estimate may be made of the fraction of the DOC pool that is turned over daily (Table 3). These estimates were made assuming a $12 \mathrm{~h}$ diel periodicity in bacterial production and respiration. This assumption was based on stable carbon isotope measurements of bacteria from these environments, which indicate that phytoplankton are the predominant substrate source (Coffin et al. 1990, Coffin \& Cifuentes unpubl. data). DOC concentrations in the estuarine and marsh samples ranged between 3.0 and $30.0 \mathrm{mg} \mathrm{C} \mathrm{Cl}^{-1}$, with highest concentrations measured for the estuarine tidal comparisons (Table 3). During the spring, at all sample locations, 0.1 to $3.2 \%$ of the DOC pool was turned over per day (Table 3 ). During July, at Range Point and in the mesocosm, the turnover of DOC was 16.5 and $21.6 \% \mathrm{~d}^{-1}$ respectively. 
Table 3. Turnover of DOC by bacteria estimated from estuarine, marsh and mesocosm samples. Values for the mesocosm experiment are averages for the $48 \mathrm{~h}$ time course. For calculations of the turnover values, a $12 \mathrm{~h}$ diel periodicity in bacterial activity is assumed (see the text)

\begin{tabular}{|c|c|c|c|c|c|}
\hline Site & Date & $\begin{array}{c}\mathrm{DOC} \\
\left(\mathrm{mg} \mathrm{Cl}^{-1}\right)\end{array}$ & 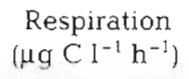 & $\begin{array}{l}\text { Production } \\
\left(\mu \mathrm{gCl} \mathrm{l}^{-1} \mathrm{~h}^{-1}\right)\end{array}$ & $\begin{array}{l}\text { Turnover } \\
\left(\% d^{-1}\right)\end{array}$ \\
\hline Santa Rosa Sound & Mar 9, 1990 & 3.0 & 2.3 & 1.2 & 1.4 \\
\hline Range Point & $\operatorname{Mar} 13,1990$ & 4.2 & 5.5 & 5.7 & 3.2 \\
\hline Range Point & Apr 2, 1990 & 12.1 & 3.6 & 3.4 & 0.7 \\
\hline Santa Rosa Sound & Apr 18,1990 & 4.3 & 2.5 & 5.6 & 2.3 \\
\hline Santa Rosa Sound & Apr 25, 1990 & 3.1 & 6.0 & 1.1 & 2.8 \\
\hline Range Point & Jul 19,1990 & 4.8 & 18.2 & 47.3 & 16.5 \\
\hline Mesocosm & July 1991 & 5.4 & 55.3 & 41.9 & 21.6 \\
\hline St. George Sound - High & May 11, 1992 & 6.6 & 3.3 & 1.6 & 0.9 \\
\hline St. George Sound - Low & May 11, 1992 & 7.6 & 2.5 & 3.9 & 1.0 \\
\hline St. Joe Bay - High & May 12, 1992 & 7.6 & 5.2 & 4.6 & 1.5 \\
\hline St. Andrews Bay - High & May 13, 1992 & 29.6 & 2.3 & 3.3 & 0.2 \\
\hline St. Andrews Bay - Low & May 13, 1992 & 14.8 & 0.9 & 0.8 & 0.1 \\
\hline Choctawahatchee - High & May 14, 1992 & 4.3 & 2.5 & 0.3 & 0.8 \\
\hline Choctawahatchee - Low & May 14, 1992 & 27.0 & 0.7 & 1.1 & 0.1 \\
\hline Pensacola Bay - High & May 15,1992 & 24.6 & 2.6 & 0.6 & 0.2 \\
\hline Pensacola Bay - Low & May 15, 1992 & 19.2 & 6.6 & 2.5 & 0.6 \\
\hline
\end{tabular}

Generally, only a small proportion of the total DOC was turned over each day. These data support the observation from this study, based on oxygen consumption, that small labile pools of organic matter support bacterial growth. Using alternative approaches similar observations regarding the turnover of DOC pools have been made. In the Chesapeake Bay, $\mathrm{DO}^{14} \mathrm{C}$ production by phytoplankton was compared to DOC concentrations to estimate that between 0.9 and $3.4 \%$ of the DOC pool was turned over daily (Malone et al. 1991). Furthermore, these observations are consistent with the finding that DOC is conservative in estuaries with regard to salinity (Mantoura 1981). In contrast, the DOC turnover was substantially larger in our mesocosm experiment and one sample date during July at the Range Point marsh. In the July mesocosm experiment, the nutrient enhanced phytoplankton production was probably the dominant source of organic matter for bacteria. In Range Point and the estuarine sites the dates are heavily weighted for samples taken during the spring. It is possible that organic matter is turned over more rapidly during the warmer summer months.

\section{CONCLUSIONS}

Oxygen consumption is a sensitive approach for examining bacterial metabolism of DOC. The advantage of this method is that all carbon respired by bacteria is accounted for in the estimate. Traditional radio-tracer studies only allow for the examination of a fraction of the substrate that is consumed by bacteria.
When oxygen consumption is combined with estimates of bacterial carbon production, growth efficiencies may be calculated.

Bacterial growth was maintained by a small labile component of the total DOC pool. This observation was supported with measurements of respiration and estimates of DOC turnover. The availability of this labile DOC varied temporally and spatially. The supply of labile organic matter appears to have important implications with regard to the role of the bacterial assemblage in processing organic matter in aquatic ecosystems. Mesocosm experiments conducted over diel cycles indicated that bacteria were closely coupled to substrate from phytoplankton. As a result, the bacterial growth efficiency varied over the diel cycle. These results suggest that the bacterial role in aquatic microbial food webs is varied. When growth conditions are adequate, cells may cycle a significant amount of carbon and nutrients to bacterial predators. When nutrients or carbon are insufficient bacteria may mineralize a greater proportion of the material that they assimilate.

The source of labile DOM was not addressed in this study. However, the rapid consumption of this material may indicate a close coupling with planktonic organisms. These results support the suggestion that bacteria are regulated, in part, by a biotic feedback mechanism in which phagotrophic protozoa are the central element responsible for supplying organic matter and nutrients to bacteria (Sherr et al. 1988). Our study was concerned with the control of carbon on bacterial assemblages. A similar potential exists for nutrients to control bacterial assemblages. We have not addressed this possibility in our study and some of the control on bacterial assem- 
blages may attributed to nutrient availability. We are addressing this question in our current research.

Results from these experiments suggest that several factors need to be considered when carbon fluxes through bacterial assemblages are estimated. Large temporal and spatial variations indicate that the dynamic nature of bacterial growth efficiency needs to be considered. Factors that control substrate availability to bacteria are regulated on varying time scales. Bacterial growth efficiency and phytoplankton production covaried over the diel cycle. Growth efficiencies in ecosystems in which bacteria depend on organic matter from other sources, such as salt marshes or terrestrial runoff, may vary on substantially longer time scales. Data from our experiments supported other studies that indicate that a small fraction of the total DOC pool supports bacterial production. Therefore, another important consideration is the length of time over which incubation experiments are conducted. Frequently, experiments that examine changes in bacterial abundance, dissolved organic matter or nutrients are conducted from one to several days. Considering the small pools and rapid turnover of organic matter, longer incubation experiments may underestimate bacterial production and growth efficiency and overestimate the contribution of more refractory compounds to bacterial growth.

Acknowledgments. We acknowledge the outstanding technical assistance of Jeff Morin and Kevin Dillon with the dock diel experiments. Consultations with Keanan Harris on the incubation experiments are greatly appreciated. Dr Mathew Hoch analyzed amino acid concentrations for tests of filtration artifact. We thank Drs Brian Fry, Bosse Norman, Richard Snyder and Mathew Hoch for reviews and helpful comments. This work was funded by U.S. EPA, Office of Research and Development, Biotechnology Risk Assessment Program and cooperative agreement \#CR815310-02, to Manhattan College funded by the same program. This manuscript is contribution no. 783 of the U.S. Environmental Research Laboratory, Gulf Breeze, Florida

\section{LITERATURE CITED}

Bauerfeind, S. (1985). Degradation of phytoplankton detritus by bacteria: estimation of bacterial consumption and respiration in an oxygen chamber. Mar. Ecol. Prog. Ser. 21: 27-36

Busch, A. W. (1958). BOD progression in soluble substrates. Proc. 13th Industrial Waste Conference, Purdue University. Lafayette, IN, p. 54-70

Bjørnsen, P. K. (1986). Automatic determination of bacterioplankton biomass by image analysis. Appl. environ. Microbiol. 51: 1199-1204

Bjarnsen, P. K., Kuparinen, J. (1991). Determination of bacterioplankton biomass, net production and growth efficiency in the Southern Ocean. Mar. Ecol. Prog. Ser. 71: 185-194

Carpenter, J. H. (1965). The Chesapeake Bay Institute technique for the Winkler dissolved oxygen method. Limnol. Oceanogr. 10: 141-143
Coffin, R. B. (1989). Bacterial uptake of dissolved free and combined amino acids in estuarine waters. Limnol. Oceanogr. 34: $531-542$

Coffin, R. B., Sharp, J. H. (1987). Microbial trophodynamics in the Delaware Estuary. Mar. Ecol. Prog. Ser. 41: 253-266

Coffin, R. B., Velinsky, D. J., Devereux, R., Price, W. A., Cifuentes, L. A. (1990). Stable carbon isotope analysis of nucleic acids to trace sources of dissolved substrates used by estaurine bacteria. Appl. environ. Microbiol. 56: $2012-2020$

Cole, J. J., Findlay, S., Pace, M. L. (1988). Bacterial production in fresh and saltwater ecosystems: a cross-system overview. Mar. Ecol. Prog. Ser. 43: 1-10

Coleman, A. W. (1980). Enhanced detection of bacteria in natural environments by fluorochrome staining of DNA. Limnol. Oceanogr. 25: 948-951

Connolly, J. P., Coffin, R. B., Landeck, R. E. (1992). Modeling carbon utilization by bacteria in natural water systems. In: Hurst, C. (ed.) Modeling the metabolic and physiologic activities of microorganisms. John Wiley and Sons, New York

Ferguson, R. L., Buckley, E. N., Palumbo, A. V. (1984). Response of marine bacterioplankton to differential filtration and confinement. Appl environ. Microbiol. 47:49-55

Fuhrman, J. A. (1987). Close coupling between release and uptake of dissolved free amino acids in seawater studied by an isotope dilution approach. Mar. Ecol. Prog. Ser 37: $45-52$

Fuhrman, J. A. (1990). Dissolved free amino acid cycling in an estuarine outflow plume. Mar. Ecol. Prog. Ser. 66: 197-203

Fuhrman, J. A., Bell, T. M. (1985). Biological consideration in the measurement of dissolved free amino acids in seawater and implications for chemical and microbiological studies. Mar. Ecol. Prog. Ser. 25: 13-21

Fuhrman, J. A., Eppley, R. W., Hagström, A., A.zam, F. (1985). Diel variations in bacterioplankton, phytoplankton and related parameters in the Southern California Bight. Mar. Ecol. Prog. Ser. 27: 9-20

Fuhrman, J. A., Ferguson, R. L. (1986). Nanomolar concentrations and rapid turnover of dissolved free amino acids in seawater: agreement between chemical and microbiological measurements. Mar. Ecol. Prog. Ser. 33: 237-242

Goldman, J. C., Caron, D. A., Dennett, M. R. (1987). Regulation of gross growth efficiency and ammonium regeneration in bacteria by substrate $\mathrm{C}: \mathrm{N}$ ratio. Limnol. Oceanogr. 32: $1239-1252$

Griffith, P. C., Douglas, D. J., Wainright, S. C. (1990). Metabolic acitivity of size-fractioned microbial plankton in estuarine, nearshore and continental shelf waters of Georgia. Mar. Ecol. Prog. Ser. 59: 263-270

Hobbie, J. E., Daley, R. J., Jasper, S. (1977). Use of Nuclepore filters for counting bacteria by fluorescence microscopy. Appl. environ. Microbiol. 33: 1225-1228

Hopkinson, C. C. Jr (1985). Shallow-water benthic and pelagic metabolism: evidence of heterotrophy in the nearshore Georgia Bight. Mar. Biol. 87: 19-32

Hopkinson, C. S. Jr, Sherr, B., Wiebe, W. J. (1989). Size fractioned metabolism of coastal microbial plankton. Mar. Ecol. Prog. Ser. 51: 155-166

Jensen, L. M., Sand-Jensen, K., Marcher, S., Hansen, M. (1990). Plankton community respiration along a nutrient gradient in a shallow Danish estuary. Mar. Ecol. Prog. Ser. 61: 75-85

Jørgensen, N. O. G., Kroer, N., Coffin, R. B., Yang, X.-H., Lee, C. (1993). Dissolved free amino acids, combined amino acids, and DNA as sources of carbon and nitrogen to marine bacteria. Mar. Ecol. Prog. Ser. 98: 135-148 
Kirchman, D., Ducklow, H., Mitchell, R. (1982). Estimates of bacterial growth from changes in uptake rates and biomass. Appl. environ. Microbiol. 44: 1296-1307

Kirchman, D. L. (1990). Limitation of bacterial growth by dissolved organic matter in the subarctic Pacific. Mar. Ecol. Prog. Ser. 62: 47-54

Kirchman, D. L., Suzuki, Y., Garside, C., Ducklow, H. W. (1991). High turnover rates of dissolved organic carbon during a spring bloom. Nature 352: 612-614

Kroer, N. (in press). Bacterial growth efficiency on natural dissolved organic matter. Limnol. Oceanogr.

Lee, S. H., Fuhrman, J. A. (1987). Relationships between biovolume and biomass of naturally derived marine bacterioplankton. Appl. environ. Microbiol. 53: 1298-1303

Malone, T. C., Ducklow, H. W., Peele, E. R., Pike, S. E. (1991). Picoplankton carbon flux in Chesapeake Bay. Mar. Ecol. Prog. Ser. 78: 11-22

Mantoura, R. F. C. (1981). Dissolved organic constituents in estuaries. In: River inputs to ocean systems, workshop proceedings, United Nations Enivronmental Programme, New York, p. 259-265

Meyer, J. L.. Edwards, R. T., Risley, R. (1987). Bacterial growth on dissolved organic carbon from a blackwater river. Microb. Ecol. 13: 13-29

Nagata, T., Kirchman, D. L. (1990). Filtration-induced release of dissolved free amino acids: application to cultures of marine protozoa. Mar. Ecol. Prog. Ser, 68: 1-5

Riemann, B., Sondergaard, M. (1984). Measurements of diel rates of bacterial secondary production in aquatic environments. Appl environ. Microbiol. 47: 632-638

Riemann, B., Nielsen, P., Jeppesen, M., Marcussen, B., Fuhrman, J. A. (1984). Diel changes in bacterial biomass and growth rates in coastal environments, determined by means of thymidine incorporation into DNA, frequency of dividing cells (FDC), and microautoradiography. Mar. Ecol. Prog. Ser. 17: 227-235

Schroeder, E. D. (1968). Importance of the BOD Plateau. Wat. Res. 2: 803-809

Sherr, B. F., Sherr, E. B., Hopkinson, C. S. (1988). Trophic interactions withir pelagic microbial communities: indications of feedback regulation of carbon flow. Hydrobiologia 159: $19-26$

Simon, M., Azam, F. (1989). Protein content and protein synthesis rates of planktonic marine bacteria. Appl.

This article was presented by $B$. and E. Sherr, Corvallis, Oregon, USA environ. Microbiol. 54: 2213-2219

Smith, R. E. H., Harrison, W G., Irwin, B., Platt, T (1986). Metabolism and carbon exchange in microplankton of the Grand Banks (Newfoundland). Mar. Ecol. Prog. Ser. 34 : $171-183$

Stoecker, D. K., Capuzzo, J. M. (1990). Pedation on protozoa: its importance to zooplankton. J. Plankton Res. 12: $891-908$

Sundh, I. (1992). Biochemical composition of dissolved organic carbon derived from phytoplankton and used by heterotrophic bacteria. Appl. environ. Microbiol. 58: $2938-2947$

Suttle, C. A., Chan, A. M., Fuhrman, J. A. (1991). Dissolved free amino acids in the Sargasso Sea: uptake and respiration rates, turnover times, and concentrations. Mar. Ecol. Prog. Ser. 70: 189-199

Tranvik, L. J. (1990). Bacterioplanktorn growth on fractions of dissolved organic carbon of different molecular weights from humic and clear waters. Appl. environ. Microb. 56: $1672-1677$

Waterbury, J. B., Valois, F. W. Franks, D. G. (1986). Biological and ecological characterization of the marine unicellular cyanobacterium Synechococcus. In: Platt, T., Li, W. K. W. (eds.) Photosynthetic picoplankton. Can. Bull. Fish. Aquat. Sci. 214: 71-120

Wikner, J., Rassoulzadegan, F., Hagström, $\AA$. (1990). Periodic bacterivore activity balances bacterial growth in the marine environment. Limnol. Oceanogr. 35: 313-324

Wright, R. T., Coffin, R. B. (1984a). Factors affecting bacterioplankton density and productivity in salt marsh estuaries. In: Klug, M. J., Reddy, C. A. (eds.) Current perspectives in microbial ecology. Proc. 3rd. int. Symp. on Microbial Ecol., Michigan State University, 7-12 August 1983. Am. Soc. for Microbiology, Washington, DC, p. 485-494

Wright, R. T., Coffin, R. B. (1984b). Measuring microzooplankton grazing on planktonic marine bacteria by its impact on bacterial production. Microb. Ecol. 10: $137-149$

Wright, R. T., Coffin, R. B., Lebo, M. (1987). Dynamics of planktonic bacteria and heterotrophic microflagellates in the Parker Estuary, Northern Massachusetts. Cont. Shelf Sci. 7: 1383-1397

ZoBell, C. E. (1943). The effect of solid surfaces upon bacterial activity. J Bacteriol 46:39-56

Manuscript first received: May 29, 1992

Revised version accepted: June 24, 1993 